\title{
Giant Condyloma Acumina or Tumor of Buschke And Lowenstein During Pregnancy: About A Case at The University Hospital of Angré, Abidjan
}

Effoh Ndrin Denis ${ }^{1 *}$, Adjoby Roland ${ }^{1}$, Kouame Arthur Didier ${ }^{2}$, Koffi Soh Victor ${ }^{1}$, Gbary-Lagaud Eleonore ${ }^{1}$, Kouakou Kouraogo R ${ }^{1}$, Diomande Fatoumata Alice ${ }^{2}$ and Koffi Kouadio Achille ${ }^{2}$

${ }^{1}$ Department of Gynecology and Obstetrics at the University Hospital of Angré, France

${ }^{2}$ Department of Gynecology and Obstetrics at the University Hospital of Cocody, France

Submission: July 01, 2020; Published: July 08, 2020

*Corresponding author: Effoh Ndrin Denis, Department of Gynecology and Obstetrics at the University Hospital of Angré, Abidjan, France

\begin{abstract}
We are reporting a rare case of giant condyloma diagnosed in a young woman with a full-term pregnancy. It is a benign tumor of viral origin that may constitute a dystocia of soft tissue during pregnancy. It is transmitted mainly by sexual transmission and the virus responsible is Human Papilloma Virus (HPV) of the types 6 and 11. It is a tumor whose benignity is related to the presence of non-oncogenic HPV. It is characterized by its recurrent and invasive evolutionary power enabling to classify it as a borderline tumor, which could explain its severity. It is a tumor that most often occurs in an immunocompromised area, but in our observation, retroviral serology was negative. The treatment is essentially surgical and must be early and radical. Its prevention is imperative, based on the treatment of acuminated condylomas and the fight against sexually transmitted diseases.
\end{abstract}

Keywords: Giant condyloma; HPV; Pregnancy

\section{Introduction}

Giant acuminous condyloma (GAC) or Buschke Lowenstein tumor (TBL) is a rare clinical entity of viral origin, transmitted mainly by sexual transmission [1]. The risk of local invasion, the strong recurrent power and the degenerative potential explain its severity [2,3]. We propose to study the particularities of this disease during pregnancy from 1 case of this tumor, observed in the gynecology and obstetrics department of the University Hospital of Angré (Abidjan).

\section{Observation}

We are reporting a case of giant acuminate condyloma (GAC) in K.Y. a 29-year-old girl with a full-term pregnancy in whom the HIV serological test is negative. This was about a fourth primiparous procedure (G4P1) with a spontaneous miscarriage of 17 weeks due to a malaria attack and an abortion at 11 weeks of amenorrhea. She was referred for a blooming giant condyloma during a 38-week pregnancy of amenorrhea. The personal medical history had nothing particular, no diabetes or sickle cell disease was noted. She was not hypertensive and was never referred for a malignant disease that required chemotherapy and radiotherapy. Besides, she has never screened for cervical cancer. The obstetrical examination concluded that the pregnancy was 38 weeks of age and not in labor. Vulva examination showed giant flourishing peri-vulvar and intra-vulvar condylomas that hindered even urination (Figure 1). Biological assessments have been carried out: The already negative HIV. serology was confirmed by a new retroviral serology by ELISA technique. N.F.S. showed microcytic hypochrome anemia with a hemoglobin level of $9.5 \mathrm{~g} / \mathrm{dl}$, syphilis serology and HBS Ag testing were negative. The biological search for possible STIs was negative.

\section{Discussion}

Our observation is a sexually transmitted viral pathology whose voluminous nature was described in 1925 by Buschke and 


\section{Global Journal of Reproductive Medicine}

Lowenstein [4]. Human papilloma virus of type 6,11 are mainly the viruses responsible for condylomas. The transformation of condylomas into TBL appears to be controlled by the immune system; TBL may be associated with congenital or acquired immunodeficiency (AIDS, immunosuppressive treatment, ethylism, diabetes, chemotherapy) [5]. In our observation, there is no pathology or immunosuppressive defects. However, in addition to pregnancy, there are also the modest socio-economic conditions of pregnancy associated with anemia of deficient origin. In western countries and in France in particular, the prevalence of condylomas or genital warts is about $1 \%$ of the sexually active population [6]. But the appearance of the quadrivalent prophylactic vaccine, capable of preventing the occurrence of most condylomas, should change the frequency and importance of this problem [6,7]. In Côte dIvoire, there has been no study on the prevalence of this disease. However, the CAG is found in several other clinical specialties: gastroenterology, urology and dermatology. Giant condylomas occur at all ages with an average age of 45 years. But for women, it is especially during periods of genital activity with a peak between 25 and 30 years of age [5] as is the case in our observation where the pregnant woman is 29 years of age. Pregnancy being one of the favoring factors could explain the prevalence of condylomas in this age group. Multiple partners, prostitution, homosexuality, poor hygiene and chronic infections contribute to HPV infection [8]. In the Reichenbach study, TBL were common in males (77\%), with penile localization in 81 to $94 \%$ and in 10 to $17 \%$ of cases in the anorectal area [9]. Urethral localization is $5 \%$ of cases in some series [10]. In women, localization is essentially vulval in $90 \%$ of cases, unlike anorectal localization, which remains less frequent [9]. In our pregnant woman, the ano-rectal examination is without particularity, the vulval localization was the essential site of the lesion. Clinically, GACs most often begin with small rounded or pinkish filiform lesions or lesions of normal skin color. The duration of the transformation varies from a few months to several years. During the condition phase, a large tumor (which can exceed $10 \mathrm{~cm}$ of major axis) is observed, papillomatous, irregular, with a surface bristling with digitations, flourishing, cauliflower-shaped, often whitish or yellowish in color, often with superficial ulcerations and added infectious lesions [9,11]. The clinical description as made by Maimon and Sykes [12,13] may appear to be the same as in our case. In Ms. KY, several small perivulval nodules were described and they increased in size with gestational age and subsequently became complicated by urinary disorders. The other tests: dermatological, digestive (ano-rectal) and urinary were without particularity. The urinary disorders could be explained by the position of one of the giant condylomas located under the base of the urethra (Figure 1). The presence of bleeding, infiltration of the base or the presence of adenopathy should make malignant degeneration suspect [14] these signs have not been found in our pregnant woman.



Figure 1: Clinical appearance of a large tumor $($ size $>10 \mathrm{~cm})$ with flourishing and vegetative lesions with vulvo-perineal and vulvo-vaginal locations.

\section{Paraclinical}

Although pregnancy is a contributing factor to the occurrence of condyloma, the flourishing and disseminated nature of these lesions should lead to the search for other sources of immuno depression. HIV serology by ELISA technique was negative. The other biological assessments related to STIs (syphilis, gonorrhea, hepatitis B and C, chlamydia trachomatis) are normal. The cervicovaginal smear did not show any precancerous lesions. Biopsy of the lesion provides histological confirmation and allows for the search for possible foci of degeneration $[9,15]$. In microscopy [16] TBL is a perfectly limited squamous tumor, characterized by considerable epithelial hyperplasia, sometimes pseudo-epitheliomatous, with the basement membrane still intact, hyperacontosis, hyper papillomatous and koilocytes that are pathognomonic markers of HPV infection, however their presence is not constant [9]. The identification of HPV, which was not investigated in our study, can be performed by electron microscopy, immuno-histochemical methods and finally the molecular biology technique either by hybridization or by PCR [17]. However, PCR remains the most sensitive and widely used method, often showing the presence of HPV 6 and 11 DNA [18]. 


\section{Global Journal of Reproductive Medicine}

\section{Treatment}

We opted for two surgical procedures: first the classical caesarean section at term (Figure 2) and then the CAG surgery, which consisted of a broad surgical removal of the lesion without removing an organ (Figure 3) The circumstances of the discoveries, the appearance of the benign tumor and especially the absence of lymph nodes made it possible to postpone the lymph node cleaning. Medical treatment was instituted as a first-line treatment after cicatrization with Podophylline. Immunomodulators should be instituted as a second line of action; however, we lost sight of the patient as soon as medical treatment with Podophylline was initiated. In literature, surgery appears as the treatment of choice because it is the most effective, especially during the early stage of the disease $[15,19]$ and allows histological analysis of the whole piece with search for foci of degeneration [20]. The excision can be completed by adjuvant treatment with chemotherapeutic and immune modulating agents [21] (Interferon or Imiquimod). Podophylline, which was the only chemical, antimitotic means used in our study (apart from pregnancy and breastfeeding). But its success does not seem to be totally in agreement with some authors $[9,12,16]$ because of its neurotoxic and hematotoxic effects and even causing necrosis of the treated tissues [22]. However, it remains more effective on young TBL [16]. Radiotherapy of Buschke-Lowenstein tumors is not recommended because it would promote malignant transformation [23]. Malignant transformation of TBL is estimated at between $8.5 \%$ and $23.8 \%$ [9]. The most frequent histological type is represented by squamous cell carcinoma [15].

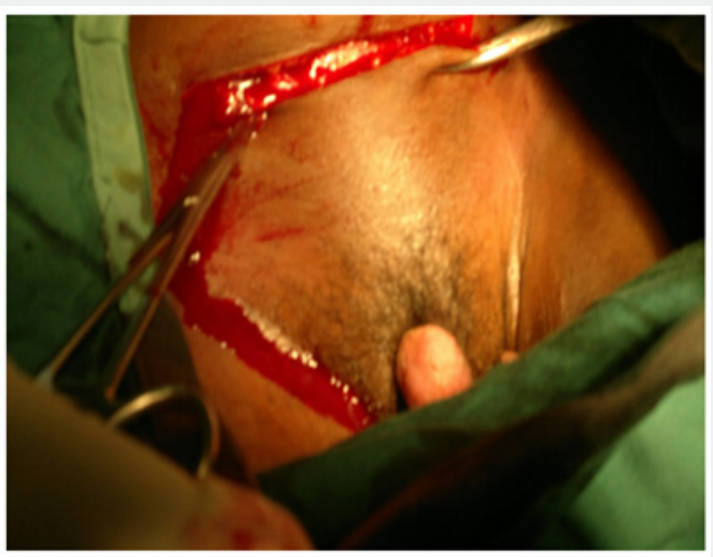

Figure 2: Operative view of an abdominal incision after the first-time caesarean section.

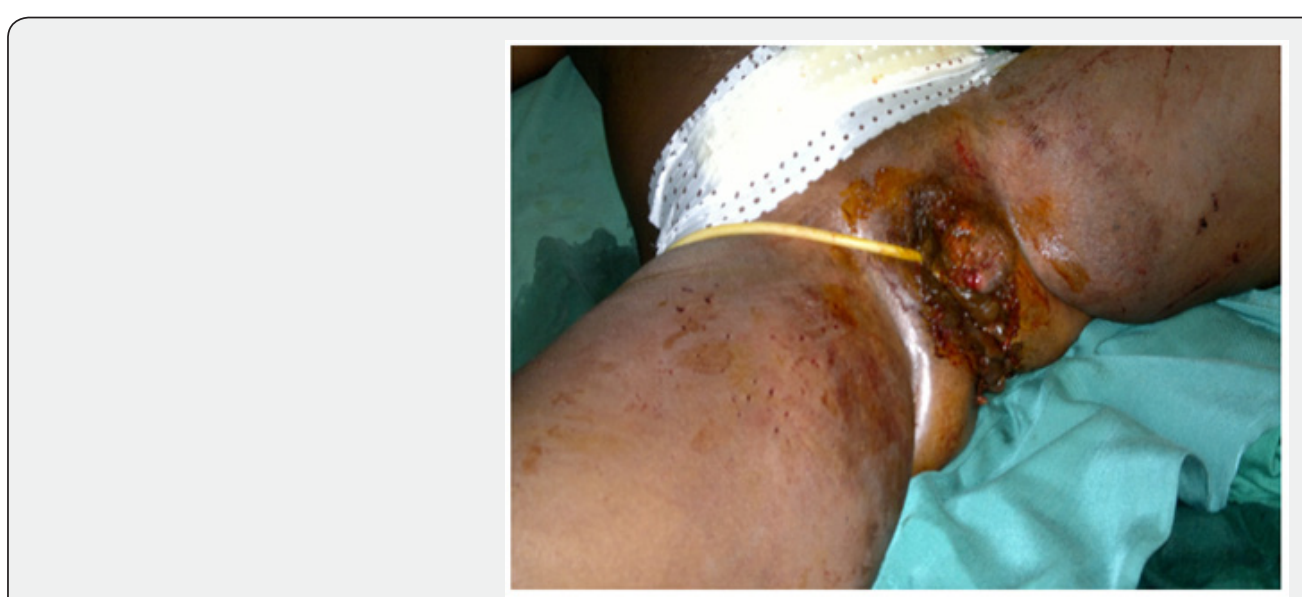

Figure 3: Post-operative view after caesarean section and broad resection of tumor lesions.

\section{Conclusion}

The CAG or Buschke-Lowenstein tumor (TBL) is a rare tumor of viral origin. It is a tumor with recurrent potential and uncertain evolution that can evolve into squamous cell carcinoma. Treatment is essentially surgical and must be early and broad. Its prevention is imperative based on the treatment of acuminated condylomas and the fight against sexually transmitted infections. Rigorous clinical and histological post-operative monitoring is required, without losing sight of the notion of recurrence or even degeneration. 


\section{Global Journal of Reproductive Medicine}

\section{References}

1. Njoumi N, Tarchouli M, Ratbi MB, Elochi MR, Yamoul R (2013) La tumeur de Buschke-Lowenstein anorectale: à propos de 16 cas et revue de la littérature. Pan Afr Med J 16: 131.

2. Kasmaoui El, Lezrak M, Ameur A (2002) Tumeurs de Buschke Loewenstein à localisation génitale, À propos de quatre observations. Ann Urol (Paris) 36(3): 211-216.

3. Gillard P, Vanhooteghem O, Richert B, De La Brassinne M (2005) Tumeur de Buschke Löwenstein. Ann Dermatol Venereol 132(1): 9899.

4. Buscke A, Loewenstein L (1925) Uber carcinomähnliche condylomata Acuminata der penis. Klin Wochenschr 4: 1726-1728.

5. Belley Priso E, Nana Njamen T, Mboudou E, Doh Sama A (2009) Un condylome Géant péri anal et vulvaire traité par excision à lhôpital général de Douala. Health Sci Dis 10(2): 27-28.

6. Monsonego J, Zerat L, Syrjänen K, Zerat JC, Smith J, Halfon P (2012) Prevalence of type-specific human papillomavirus infection among women in France: Implications for screening, vaccination, and a future generation of multivalent HPV vaccines Vaccine 30 (35): 5215-5221.

7. Vinatier D, Cosson M, Dufour P (2000) Accinothérapies prophylactiques et thérapeutiques dans les infections à papilloma virus. Gynecol Obstet Fertil 28: 370-384.

8. El Mejjad A, Dakir M, Tahiri M, Attar H, Cherkaouia A (2003) Le condylome acuminé géant-tumeur de Buschke Lowenstein à propos de 3 cases. Progrès en Urologie 20(13): 513-517.

9. Reichenbach I, Koebell A, Foliguet B, Hatier H, Hascotti J, et al. (1995) Tumeur de Buschke et Lowenstein à propos dun cas féminin. J Gynecol Obstet Biol Reprod 24: 491-495.

10. Le Guillou M, Géniaux M, Mugnier C, Ferrière J, Texier L (1979) Localisation urétrales dune maladie de Buschke Lowenstein et d'une tumeur de lurètre J Urol Nephr 85: 175-176.

11. Villote J, Benhamou G, Alcabes G, Vissuzaine C, Toublanc M (1989) Tumeur de Buschke Lowenstein anorectale (condylomatose géante) nécessitant une amputation du rectum. Gastroentérologie Clin Biol 13: 105-107.

12. Maymon R, Bekerman A, Werchow M, Maymon B, Segal R (1995) Factor J Clinical and subclinical condyloma: rates among sexual Partner of women with genital human papillomavirus infection. J Reprod Med 40: 31-36.

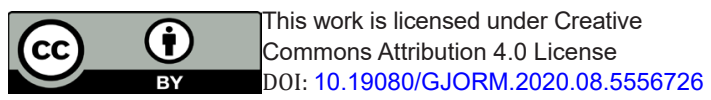

13. Sykes NL (1995) Condyloma acuminatum. Int J Dermatol 34: 297-302.

14. Ben Brahim E, Chadli Debbiche A, Fraoua Abdelmoula F, Lahmar Boufaroua A, Bouchoucha S (2000) Condylome géant de BuschkeLöwenstein de la région périanale avec envahissement inguinal: à propos dun cas 1. Barrasso R. Savoir traiter les condylomes externes. Gyn Obs 426: 18-19.

15. Kabiri H, Albouzidi A, Rachid K, Lezrek M, Bous Selman N (1996) Tumeur de Buschke Lowenstein scrotale dégénérée. Progrès en urologie 6: 439-442.

16. Buffet M, Aynaud O, Piron D, Dupin N, Escande JP (2002) Tumeur pénienne de Buschke-Löwenstein Progrès en Urologie 12: 332-336.

17. Rijkaart DC, Berkhof J, Rozendaal L, Van Kemenade FJ, Bulkmans NW, et al. (2012) Human papillomavirus testing for the detection of highgrade cervical intraepithelial neoplasia and cancer: final results of the POBASCAM randomised controlled trial. Lancet Oncol 13(1): 78-88.

18. Insinga RP, Dasbach EJ, Elbasha EH Liaw KL, Barr E (2007) Incidence and duration cervical human papillomavirus 6,11,16, and 18 Infections in young women: an evaluation from multiple analytic perspectives. Cancer Epidemio Biomarkers Prev 16(4): 709-715.

19. Asvesti C, Delmas V, Dauge Geffroy M, Grossin M, Boccon Gibod L, et al. (191) Condylomes multiples de lurètre et de la vessie révélant une infection par HIV. Ann Urol 25: 146-149.

20. Benchekroun A, Nouini Y, Zennoud M, Kermouni T, Iken A (2002) Verrucous carcinoma and Buschke-Löwenstein tumors: A propos of 2 cases. Ann Urol 36: 286-289.

21. Vexiau D, Decuypére L, Moyse D, Aractingi S (2005) Efficacité et tolérance de limiquimod crème $5 \%$ dans le traitement des condylomes acuminés externes résultats dun suivi à 6 mois. Ann Dermatol Venerol 132: 845-851.

22. Cusini M, Salmaso F, Zerboni R, Carminati G (2004) 5\% Imiquimod cream for external anogenital warts in HIV-infected patients under HAART therapy. Int J Std Aids 15: 17-20.

23. Majewski S, Jablonska S (1997) Human papillomavirus associated tumors of the skin and mucosa. J Am Acad Dermatol 36: 659-685.

Your next submission with Juniper Publishers
will reach you the below assets
- Quality Editorial service
- Swift Peer Review
- Reprints availability
- E-prints Service
- Manuscript Podcast for convenient understanding
- Global attainment for your research
- Manuscript accessibility in different formats
( Pdf, E-pub, Full Text, Audio)
- Unceasing customer service
Track the below URL for one-step submission
https://juniperpublishers.com/online-submission.php

